\title{
Peningkatan Hasil Belajar dan Keaktifan Siswa pada Pembelajaran Tugasku Sehari-hari dengan Menggunakan Model Pembelajaran Make a Match di Kelas II SDN 2 Cingkrong
}

\author{
Susilowati \\ SDN 2 Cingkrong \\ susilowati31@gmail.com
}

\author{
Article History \\ accepted 01/11/2020
}

approved 08/11/2020

published 15/11/2020

\begin{abstract}
This research was conducted because of the low learning outcomes of grade II at SDN 2 Cingkrong. The method that researchers used in this classroom action research was the Make a Match cooperative learning model in which there were 4 stages, namely planning, action, observation and reflection. The subjects of this study were class II students of SDN 2 Cingkrong which consisted of 26 students. Data collection was carried out. Researchers through observation, interviews, tests and documentation. The results showed that 1) The application of the Make a Match type of cooperative model can increase the activity of teachers and students. On the results of observations of teacher activity in cycle I is 72.52, and increased to 90.32 in the cycle II. Meanwhile, the results of student activity observations in cycle I were 70.83 , and increased to 91.7 in cycle II. 2) The increase in student learning outcomes can be seen from the average score of students in the Indonesian language subject at Pre PTK of 63.7 with a percentage of $46.15 \%$, in the first cycle it became 72.7 , with a percentage of $69.23 \%$, and increased to 77 . with a percentage of $80.8 \%$ in cycle II. Mathematics also increased, namely at the beginning of the cycle of 64.1, with a percentage of $42.30 \%$, in the first cycle it became 695 with a percentage of $57.7 \%$ and increased to 77 , with a percentage of 80.76 . In cycle II.
\end{abstract}

Keywords: learning outcomes, student activity, make a match

\begin{abstract}
Abstrak
Penelitian ini dilakukan karena rendahnya hasil belajar kelas II di SDN 2 Cingkrong. Metode yang peneliti gunakan pada penelitian tindakan kelas ini adalah model pembelajaran kooperatif tipe Make a Match yang didalamnya terdapat 4 tahap yaitu perencanaan,tindakan,observasi dan refleksi.Subyek penelitian ini adalah siswa kelas II SDN 2 Cingkrong yang terdiri dari 26 siswa.Pengambilan data dilakukan peneliti melalui observasi,wawancara,tes dan dokumentasi.Hasil penelitian menunjukkan bahwa 1) Penerapan model kooperatif tipe Make a Match dapat meningkatkan aktivitas guru dan siswa.Pada hasil observasi aktivitas guru pada siklus I yaitu72,52, dan meningkat menjadi 90,32 pada siklus II.Sedangkan hasil obsevasi aktivitas siswa pada siklus I yaitu 70,83, dan meningkat menjadi 91,7 pada siklus II. 2)Peningkatan hasil belajar siswa dapat dilihat dari nilai rata-rata siswa mata pelajaran Bahasa Indonesia padaPra PTK sebesar 63,7 dengan prosentase $46,15 \%$,pada siklus I menjadi 72,7 , dengan prosentase $69,23 \%$,dan meningkat menjadi 77 ,dengan prosentase $80,8 \%$ pada siklus II.Pada mata pelajaran matematika juga mengalami peningkatan yakni pada awal siklus sebesar 64,1 ,dengan prosentase $42,30 \%$,pada siklus I menjadi 695 dengan prosentase $57,7 \%$ dan meningkat menjadi 77 ,dengan prosentase 80,76 .Pada siklus II.
\end{abstract}

Kata kunci: hasil belajar, keaktifan siswa, make a match

Social, Humanities, and Education Studies (SHEs): Conference Series https://jurnal.uns.ac.id/shes

p-ISSN 2620-9284 e-ISSN 2620-9292 


\section{PENDAHULUAN}

Pendidikan merupakan aspek yang sangat penting dalam menunjang kemajuan bangsa ke depan .Melalui pendidikan,manusia sebagai subyek dapat di didik.di bina dan dikembangkan potensi-potensinya .Pendidikan bertujuan untuk mengembangkan potensi peserta didik agar dapat menjadi manusia yang beriman,berilmu,cakap,kreatif,mandiri,dan menjadi warga negara yang demokratisserta bertanggung jawab.

Pencapaian tujuan pendidikan tersebut menjadi tantagan termasuk peningkatan mutu ,relevansi,dan efektivitas pendidikan sebagai tuntutan nasional sejalan dengan perkembangan dan kemajuan masyarakat,berimplikasi secara nyata dalam program pendidikan dan kurikulum sekolah Akan tetapi banyak permasalahan dalam pendidikan yang yang dapat menghambat tercapainya tujuan itu,salah satunya adalah (1) Kurangnya minat siswa dalam pembelajaran; (2) Kurangnya keaktifan siswa dalam pembelajaran; (3) Rendahnya hasil belajar siswa di bawah KKM; (4) Kurangnya pengetahuan guru dalam penerapan model pembelajaran; (5) Penyampaian materi dari guru yang kurang menarik.

Berdasarkan permasalahan tersebut maka sebagai pendidik sangat penting untuk memahami karaktristik peserta didik dan strategi pembelajaran yang akan digunakan pada sat mengajar.Salah satu pembelajaran yang dikenal efektif adalah pembelajaran yang bersifat melibatkan siswa dalam berinteraksi di dalam kelas yaitu dengan pembelajaran kooperatif. Model pembelajaran kooperatif adalah salah satu model pembelajaran yang dapat meningkatkan aktifitas peserta didik meningkatkan daya nalar,cara berfikir logis,aktif,kreatif,terbuka,serta ingin tahu.

Selain itu ,model kooperatif mampu meningkatkan perluasan siswa untuk aktif dalam pembelajaran Model kooperatif mempunyai tipe-tipe salah satu tipenya adalah Make a match yang dikembangkan oleh Lorna curran. Sedangkan Kurniasih dan Sani menyatakan bahwa make a match adalah suatu model pembelajaran dimana siswa diajak mencari pasangan sambil belajar mengenai suatu konsep atau topik dalam suasana belajar menyenangkan.

Model pembelajaran make a match ialah model pembelajaran secara berkelompok yang mengajak siswa untuk memahami konsep dan topik pembelajaran dalam situasi yang mengasyikkan melalui media kartu jawaban dan kartu pertanyaan. Dalam pelaksanaannya, model ini memiliki batasan waktu maksimum yang sudah ditentukan sebelumnya. Kelebihan dari model pembelajaran make a match, diantaranya: (1) mewujudkan kondisi pembelajaran yang mengasyikkan; (2) materi belajar disajikan lebih menarik perhatian peserta didik; (3) dapat memperbaiki hasil belajar peserta didik guna mencapai taraf ketuntasan belajar; (4) Kerjasama antarsesama peserta didik terwujud dengan dinamis (Kurniasih dan Berlin, 2015: 56).

Make a match adalah model pembelajaran dimana peserta didik belajar dalam kondisi yang mengasyikkan dengan cara mencari pasangan sembari mempelajari suatu konsep dan topik tertentu (Huda, 2015: 135). Sedangkan menurut Shoimin (2014:99) Make a match ialah model pembelajaran yang menggunakan kartu jawaban dan kartu soal dimana dalam pengaplikasiannya tiap siswa mencari pasangan kartu yang berisi soal maupun jawaban dari materi belajar tertentu. Berdasarkan beberapa pendapat para ahli diatas, penulis menyimpulkan model pembelajaran make a match adalah model pembelajaran secara berkelompok yang mengajak siswa untuk memahami konsep dan topik pembelajaran melalui media kartu jawaban dan kartu pertanyaan serta dalam pelaksanaannya memiliki batasan maksimum waktu yang sudah ditentukan sebelumnya.

Adapun langkah-langkah model pembelajaran make a match menurut Shoimin (2014: 98-99) adalah (a) guru melakukan persiapan dengan membuat beberapa kartu yaitu kartu pertanyaan dan kartu jawaban. (b) masing masing peserta didik mendapatkan satu jenis kartu. (c) tiap peserta didik berpikir mengenai soal atau 
jawaban kartu yang sudah dipegang. (d) tiap peserta didik diminta mencari pasangan kartu yang memiliki kecocokan dengan kartu yang dipegang. (e) tiap peserta didik yang dapat menemukan kecocokan kartu sebelum mencapai batasan waktu maksimum, maka diberikan poin. (f) apabila sudah selesai satu sesi, dilakukan pengocokan kartu lagi supaya setiap peserta didik memeroleh kartu yang tidak sama dari kartu di sesi satu. (g) guru dan peserta didik menyimpulkan pembelajaran.

Hasil belajar ialah berbagai perubahan yang menyangkut aspek kognitif, psikomotor dan afektif yang didapat siswa sebagai dampak dari aktivitas belajar (Rusman, 2017: 129). Definisi hasil belajar juga dikemukakan oleh Nawawi (dalam Susanto, 2016: 5) yang mengemukakan bahwa hasil belajar adalah skor yang diperoleh siswa yang menunjukkan tingkat keberhasilannya dalam menuntaskan materi pelajaran tertentu. Berdasarkan beberapa pendapat para ahli diatas, penulis menyimpulkan bahwa hasil belajar ialah keberhasilan siswa setelah siswa belajar mengenai materi pembelajaran tertentu yang menyangkut aspek kognitif, psikomotor dan afektif. Hasil belajar dijadikan sebagai umpan balik bagi guru untuk mendeteksi materi pembelajaran yang disampaikan mampu diterima siswa atau tidak.

Berdasarkan latar belakang tersebut, saya tertarik untuk melakukan penelitian yang berjudul Peningkatan hasil belajar dan keaktifan siswa pada pembelajaran tugasku sehari - hari dengan menggunakan model pembelajaran cooperatif tipe make a match di SDN2 Cingkrong tahun 2020/2021.

\section{METODE}

Penelitian ini menggunakan rancangan Penelitian Tindakan Kelas (PTK). PTK berasal dari masalah yang ditemukan oleh guru selama melakukan kegiatan pembelajaran dikelas. Menurut Arikunto (2010: 135) PTK merupakan penelitian yang dilaksanakan oleh guru di kelasnya yang memiliki maksud untuk meningkatkan dan memperbaiki kualitas pembelajaran di kelas.. Dengan adanya penelitian ini, guru dapat mendeteksi kelemahan kelemahan yang dialami siswa dan melakukan tindakan untuk menangani permasalahan siswa tersebut. Penelitian ini dilakukan dengan harapan guru dapat merefleksi diri mengenai layanan pendidikan yang telah diberikan kepada siswa sehingga dapat memperbaiki mutu pembelajaran di lembaga sekolah. PTK ini akan menggunakan penelitian secara bersiklus. Peneliti merancang 2 siklus. Apabila hasil penelitian yang ada di siklus I dan II belum mencapai hasil yang maksimal, maka akan diadakan penelitian di siklus berikutnya. Penelitian ini akan menerapkan prosedur PTK yang dikembangkan oleh Kemmis dan Mc Taggart. Tahapan pada penelitian ini meliputi 3 tahap, yakni (1) Perencanaan; (2) Perlakuan dan Pengamatan; serta (3) Refleksi.. Tahapan penelitian PTK ini dapat digambarkan pada bagan berikut:

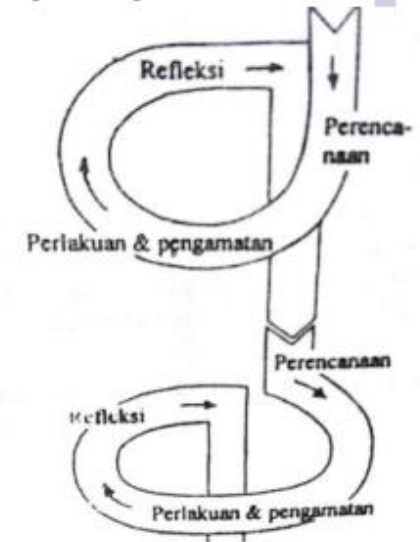

Gambar 1.Bagan Siklus PTK Kemmis dan Mc Taggart

(dalam Arikunto, 2010: 132) 
Pada tahap perencanaan, peneliti menganalisis kurikulum KTSP guna menentukan SK dan KD serta membuat indikator yang akan digunakan, merancang dan membuat Perangkat Pembelajaran, membuat instrumen penelitian yang berisi lembar penilaian pelaksanaan pembelajaran, lembar penilaian hasil belajar, dan lembar catatan lapangan. Tahap selanjutnya ialah Perlakuan dan Pengamatan. Tahap perlakuan merupakan implementasi dari isi rancangan yang telah disusun sebelumnya. Pada tahap perlakuan, peneliti dan guru berkolaboratif melaksanakan kegiatan pembelajaran dengan menggunakan model pembelajaran make a match. Sedangkan pada tahap pengamatan, peneliti akan mengamati seluruh rangkaian kegiatan yang dilakukan oleh guru dan siswa selama kegiatan pembelajaranyang menerapkan model pembelajaran make a match. Adapun yang menjadi observer adalah peneliti sendiri dan teman sejawat. Pengamatan dilakukan dengan maksud untuk mengetahui ketersesuaian antara RPP dengan pelaksanaannya di kelas serta untuk mendeteksi kendala yang dialami saat kegiatan belajar mengajar sedang berlangsung. Tahap refleksi dilakukan peneliti dan guru untuk berdiskusi bersama guna mengkaji secara keseluruhan mengenai hasil pengamatan dan hasil tes yang sudah dilakukan. Hal ini dimaksudkan untuk melakukan evaluasi bersama menemukan kekurangankekurangan di siklus sebelumnya guna memperbaiki dan menyempurnakan tindakan di siklus berikutnya.

Dalam melaksanakan siklus II sebenarnya memiliki kesamaan pada saat melaksanakan siklus I, yang membedakan yaitu siklus II dilakukan penyempurnaan hal-hal yang kurang sesuai di siklus I. Apabila di siklus II hasil yang diperoleh masih belum optimal dan dirasa masih kurang, maka perlu dilakukan penelitian siklus III guna memperbaiki masalah tersebut.

Pada penelitian ini, subjek yang diteliti ialah siswa kelas II SDN 2 Cingkrong tahun pelajaran 2020/2021 pada saat pembelajaran tematik. Jumlah keseluruhan siswa kelas $\mathrm{V}$ ada 26 siswa yang terdiri dari 10 laki-laki dan 6 perempuan. Teknik pengumpulan data yang digunakan adalah observasi, tes dan catatan lapangan. Teknik observasi ini dipergunakan guna mengumpulkan data mengenai pelaksanaan pembelajaran dengan menggunakan instrumen lembar pengamatan yang diisi selama kegiatan pembelajaran berlangsung. Untuk mengumpulkan data hasil belajar siswa digunakan tes. Tes ini dapat berupa lembar evaluasi yang berisikan soal pilihan ganda, isian dan uraian yang diberikan guru diakhir proses pembelajaran. Sedangkan catatan lapangan untuk mencatat hal-hal yang terjadi selama kegiatan belajar mengajar berlangsung. Berdasarkan lembar catatan lapangan ini, dapat diketahui kendala atau masalah yang muncul pada saat kegiatan pembelajaran.

Indikator keberhasilan yang terdapat dalam penelitian ini meliputi: (1) Pelaksanaan pembelajaran dikatakan berhasil apabila hasilnya mencapai tingkat keberhasilan $\geq 80 \%$. (2) Siswa dapat dikatakan tuntas belajar apabila memeroleh nilai yang mencapai KKM yaitu $\geq 70$. Sedangkan ketuntasan belajar klasikal jika semua siswa mencapai keberhasilan sebesar $\geq 80 \%$.

\section{HASIL DAN PEMBAHASAN}

Penerapan model kooperatif tipi make a match pada subtema tugasku seharihari di rumah pada kelas II di SDN 2 Cingkrong dapat dikatakan berhasil karena terdapat peningkatan aktivitas guru dan siswa dari siklus I ke siklus II.Peningkatan tersebut dapat disimpulkan dalam diagram berikut: 
SHEs: Conference Series 3 (3) (2020) $20-27$

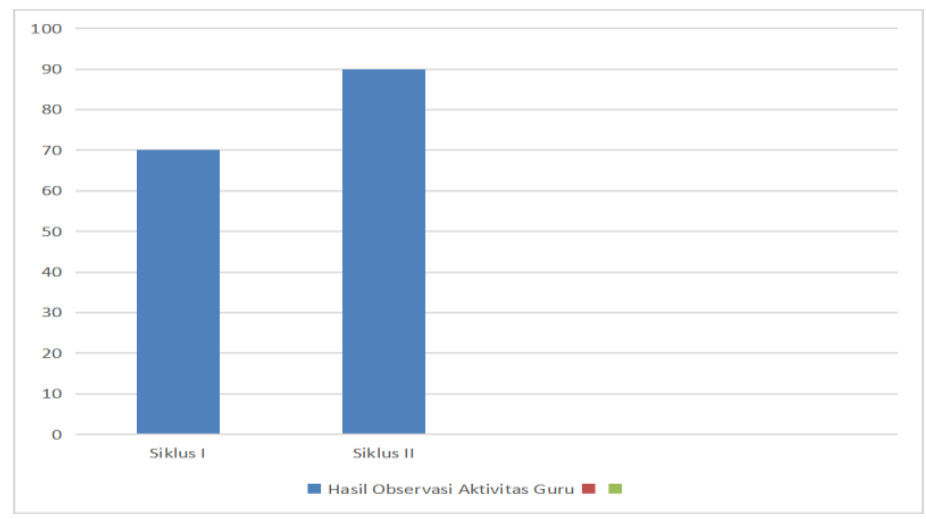

\section{Gambar 1. Hasil Observasi Aktivitas Guru}

Dari diagram diatas dapat diketahui bahwa aktivitas guru pada siklus I dan siklus II mengalami peningkatan.Pada siklus I memperoleh nilai sebesar 72,8 dan hasil tersebut di katakan belum tuntas karena belum mencapai kriteria minimal yakni 80.Tidak maksimalnya aktivitas guru di sebabkan oleh beberapa faktor seperti guru terlalu cepat berbicara,guru kurang fokus dalam mengajar dan lain sebagainya.Sedangkan pada siklus II di peroleh hasil sebesar 90,32, dibanding dengan siklus I,pada siklus II ini terdapat peningkatan dan sudah dapat dikatakan sudah berhasil di karenakan sudah mencapai keberhasilan dalam proses pembelajaran .Keberhasilan dalam tindakan pada siklus II ini dikarenakan adanya evaluasi pada siklus I sehingga lebih dimaksimalkan pada siklus II seperti pada penyampaian materi yang lebih tenang dan pelan -pelan.

Hasil observasi aktivitas peserta didik dapat dilihat pada gambar berikut:

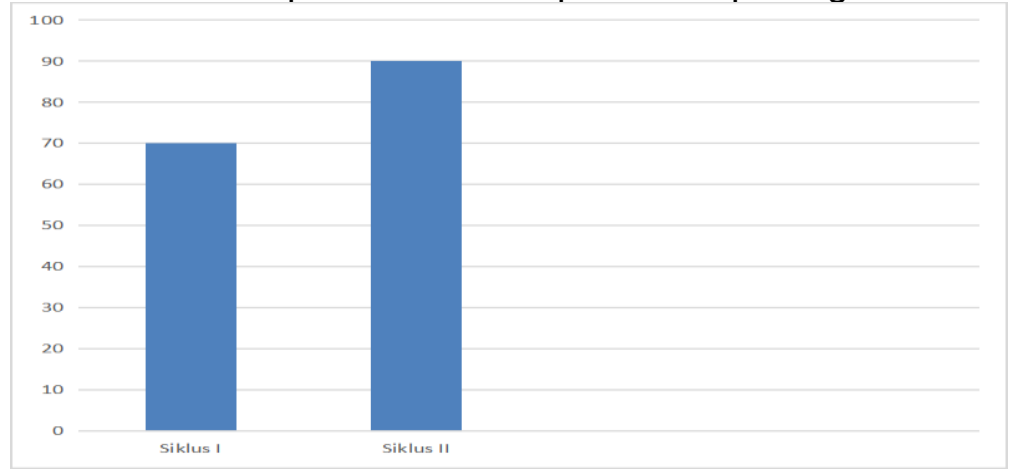

\section{Gambar 2. Hasil Observasi Aktifitas Peserta Didik}

Dari diagram di atas,dapat diketahui bahwa terjadi peningkatan dari siklus I ke siklus II. Pada siklus I memperoleh nilai sebesar 70,83. Hasil tersebut dikatakan belum tuntas karena tidak memenuhi kriteria minimum yakni 80.Proses pembelajaran pada siklus I siswa kurang aktif saat diberi pertanyaan ,siswa juga sering bicara sendiri saat proses pembelajaran .Sedangkan pada siklus II memperoleh nilai sebesar 91,7 dan sudah dapat dikatakan tuntas atau berhasil karena sudah mencapai kriteria minimal yakni 80.Secara keseluruhan siswa dapat mengikuti pembelajaran dengan baik seperti dalam bekerjasama kelompok ataupun keaktifannya.Hal ini sesuai dengan kelebihan model kooperatif yaitu suasana kegembiraan akan tumbuh dalam proses pembelajaran ,kerja sama antar siswa tercipta dengan dinamis,munculnya dinamika gotong royong yang merata pada seluruh siswa.Menghindari kejenuhan siswa dalam mengikuti pembelajaran,karena siswa terlibat langsung dalam menjawab soal yang disampaikan kepadanya melalui media kartu.Hal ini karena fungsi media adalah sebagai alat bantu dalam proses pembelajaran untuk mempermudah siswa dalam 
memahami materi sehingga dapat mempertinggi daya serap siswa terhadap materi pembelajaran.

Dalam Penelitian Tindakan Kelas (PTK) yang telah dilakukan sejak prasiklus,siklus I dan siklus II mendapat hasil yang meningkat .Hasil belajar selalu meningkat pada setiap siklusnya.Pada tindakan siklus I dan II,peneliti menerapkan model kooperatif tipe make a match yang terdapat tahapan berdiskusi .Berikut akan diuraikan hasil ketuntasan siswa pada tiap siklusnya.

Pada saat peneliti melakukan observasi di SDN 2 Cingkrong diketahui nilai hasil pembelajaran pada Subtema tugasku sehari-hari di rumah ini sangat rendah hal ini di buktikan dengan banyak siswa yang mendapat nilai di bawah KKM .Jumlah siswa yang tuntas pada mata pelajaran Bahasa Indonesia hanya 12 siswa sedangkan pada mata pelajaran Matematika hanya 11 siswa.Hasil pre-test pada pembelajaran Subtema tugasku sehari-hari di rumah dapat dilihat diagram di bawah ini

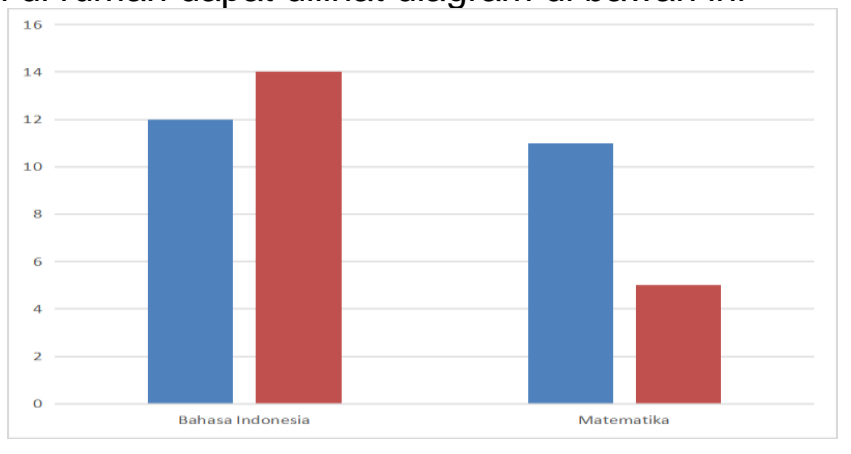

Gambar 3. Hasil Belajar Awal Siklus

Pada siklus I peneliti menerapkan model kooperatif tipe make a match di kelas II SDN 2 Cingkrong untuk meningkatkan hasil belajar siswa pada subtema tugasku sehari-hari di rumah pada mata pelajaran Bahasa Indonesia dari prasiklus memperoleh $51,9 \%$ menjadi $69,23 \%$. Sedangkan pada mata pelajaran Matematika dari $55,6 \%$ menjadi $80,8 \%$

Berdasarkan nilai KKM pada mata pelajaran Bahasa Indonesia dan Matematika yaitu 70 sehingga dapat diketahui dari jumlah 26 siswa pada pembelajaran subtema tugasku sehari-hari di rumah pada mata pelajaran Bahasa Indonesia terdapat 18 siswa yang tuntas dan 8 siswa belum tuntas sedangkan pada mata pelajaran matematika menjadi 15 siswa yang tuntas dan 11 siswa tidak tuntas. Untuk menggambarkan uraian di atas dapat dilihat pada diagram berikut

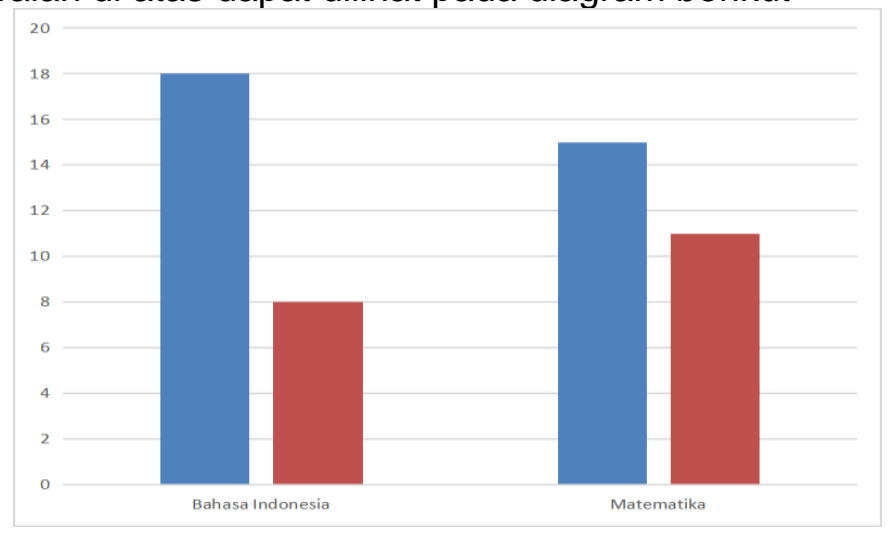

Gambar 4. Hasil Belajar Siklus I

Pada siklus II ini,hasil belajar pada pembelajaran subtema tugasku sehari-hari di rumah mengalami peningkatan yang signifikan. Pada mata pelajaran Bahasa 
Indonesia dari 26 siswa yang tuntas sudah mencapai 21 siswa dan 5 lainnya belum tuntas.Sedangkan pada mata pelajaran matematika terdapat juga 21 siswa tuntas dan 5 lainnya belum tuntas

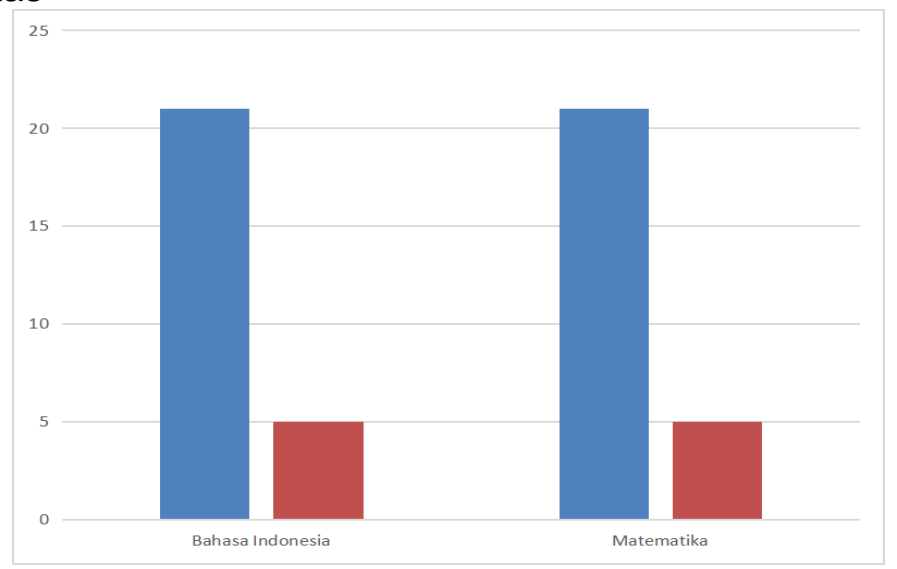

Gambar 5. Hasil Belajar Siklus II

Hasil belajar siswa dari siklus I-II mengalami peningkatan dan sudah mencapai indikator keberhasilan pada siklus II. Hal ini sejalan dengan pendapat Kurniasih dan Berlin (2017:56) bahwa salah satu keunggulan model pembelajaran make a match adalah dapat memperbaiki hasil belajar siswa guna mencapai taraf ketuntasan klasikal. Dengan adanya peningkatan hasil belajar siswa dari siklus I-II, maka kemampuan pemahaman siswa dalam menyerap materi pembelajaran juga meningkat. Hal ini dikarenakan siswa sudah mulai mengenal dan terbiasa dengan penerapan model kooperatif tipe make a match.

Pembelajaran yang menerapkan model pembelajaran kooperatif tipe make a match menjadikan siswa mandiri dan aktif saat kegiatan pembelajaran, melatih siswa untuk menggali informasi, mengidentifiksi peristiwa-peristiwa yang berkaitan dengan materi yang diajarkan serta memberikan keterampilan memecahkan masalah yang ditemukan dalam kegiatan pembelajaran. Berdasarkan ulasan pembahasan tersebut, model pembelajaran kooperatif tipe make a match dapat digunakan sebagai alternatif model pembelajaran yang dapat meningkatkan minat belajar siswa untuk mengikuti pembelajaran di kelas serta juga memiliki dampak positif terhadap kemajuan hasil belajar siswa. Dikarenakan, pada model pembelajaran kooperatif tipe make a match siswa diajak untuk mencari pasangan kartu sambil belajar mengenai suatu topik dalam suasana pembelajaran yang menyenangkan. Sehingga siswa menjadi termotivasi untuk tetap aktif menemukan pasangan kartu dan siswa akan memiliki pengalaman belajar yang bermakna. Hal ini senada dengan pendapat Shoimin (2014:98) bahwa make a match ialah model pembelajaran yang menuntut keaktifan siswa untuk bergerak aktif menemukan pasangan kartu yang sesuai dengan pertanyaan ataujawaban dalam kartu tersebut.

Berdasarkan hasil penelitian yang telah dilakukan dan merujuk pada teori Paul D. Dierich (dalam Sardiman, 2009) tentang pembagian aspek keaktifan belajar siswa dan kaitannya dengan berbagai aktivitas yang dilakukan pada pembelajaran kooperatif tipe make a match, dapat disimpulkan bahwa pembelajaran kooperatif tipe make a match dapat meningkatkan keaktifan siswa selama proses pembelajaran. Hal ini sejalan dengan yang disampaikan oleh Miftahul Huda (2013) bahwa pembelajaran kooperatif tipe make a match dapat meningkatkan aktivitas belajar siswa baik secara kognitif maupun psikomotor serta didukung dengan penelitian yang relevan dalam skripsi Eti Rahmawati (2015) dan Rosmala (2015), maka pembelajaran kooperatif tipe make a match dapat menjadi salah satu alternatif pembelajaran untuk meningkatkan keaktifan siswa. 


\section{SIMPULAN}

Berdasarkan hasil penelitian tentang penerapan model pembelajaran kooperatif tipe make a match untuk meningkatkan hasil belajar dan aktivitas iswa kelas II SDN 2 Cingkrong dapat disimpulkan bahwa 1) Penerapan model kooperatif tipe Make a Match dapat meningkatkan aktivitas guru dan siswa.Pada hasil observasi aktivitas guru pada siklus I yaitu72,52, dan meningkat menjadi 90,32 pada siklus II.Sedangkan hasil obsevasi aktivitas siswa pada siklus I yaitu 70,83 , dan meningkat menjadi 91,7 pada siklus II. 2)Peningkatan hasil belajar siswa dapat dilihat dari nilai rata-rata siswa mata pelajaran Bahasa Indonesia padaPra PTK sebesar 63,7 dengan prosentase $46,15 \%$,pada siklus I menjadi 72,7 , dengan prosentase $69,23 \%$,dan meningkat menjadi 77 ,dengan prosentase $80,8 \%$ pada siklus II.Pada mata pelajaran matematika juga mengalami peningkatan yakni pada awal siklus sebesar 64,1,dengan prosentase $42,30 \%$,pada siklus I menjadi 695 dengan prosentase $57,7 \%$ dan meningkat menjadi 77, dengan prosentase 80,76.Pada siklus II.

\section{DAFTAR PUSTAKA}

Arikunto, Suharsimi. 2010. Prosedur Penelitian Suatu Pendekatan Praktik. Jakarta: Rineka Cipta.

Eti Rahmawati. (2015). Penerapan Model Pembelajaran Make A Match untuk Meningkatkan Keaktifan dan Prestasi Belajar Siswa pada Mata Pelajaran Sosiologi Kelas XI IIS 2 di SMA Negeri 2 Surakarta pada Tahun Pelajaran 2014/2015. Skripsi: Universitas Sebelas Maret.

Huda, Miftahul. 2013. Model-ModelnPengajaran dan Pembelajaran: Isu-isu Metodis dan Paradigmatis. Yogyakarta: PustakanPelajar.

Kurniasih, Imas dan Sani, Berlin (2017). Ragam pengembangan model pembelajaran untuk peningkatan profesionalitas guru. Bandung

Mifta Dyah Rosmala. (2015). Implementasi Model Pembelajaran Make A Match sebagai Upaya Meningkatkan Partisipasi dan Hasil Belajar Siswa pada Mata Pelajaran Kompetensi Kejuruan Multimedia di Kelas X Multimedia SMK Negeri 6 Purworejo. Skripsi: Universitas Negeri Yogyakarta.

Rusman. 2017. Belajar \& Pembelajaran Berorientasi Standar Proses Pendidikan. Jakarta: Kencana.

Sardiman. (2009). Interaksi dan Motivasi Belajar Mengajar. Jakarta: Rajawali Pers.

Shoimin, Aris. 2014. 68 Model Pembelajaran Inovatif dalam Kurikulum 2013. Yogyakarta: Ar-Ruzz Media.

Susanto, Ahmad. 2016. Teori Belajar dan Pembelajaran di Sekolah Dasar. Jakarta: Prenadamedia Group 